\title{
Analysis of Risk Management Assessment on Quality Control Services using Framework COBIT 5
}

\author{
Ade Purwanto \\ Department of Information System \\ Universitas Ahmad Dahlan \\ Yogyakarta of Indonesia
}

\author{
Imam Riadi \\ Department of Information System \\ Universitas Ahmad Dahlan \\ Yogyakartaof Indonesia
}

\begin{abstract}
Quality Control referred to in PT. Woolu Aksara Maya Yogyakarta is controlling the process of making the company's web application so that it is hoped that there will be no errors that occur in the company's web application. However, in reality, there are still errors in the application so that the business processes carried out by the company are still not optimal, because there are still many application features that are still not running well. The purpose of this research is to assess the Capability Level (maturity level), calculate the value gap, and provide recommendations by the APO12 (manage risk) and EDM03 (ensure risk optimization) domains. The risk management assessment in this research uses the COBIT 5 framework using the APO12 (process domains manage risk) and EDM03 (ensure risk optimization) which include stages of data collection, risk analysis, risk profile, risk articulation, risk tolerance value, how to respond to risk, evaluate risk management, and direct risk management. The stages of research conducted in this research have three stages of analysis the research, namely determining the current capability level and the expected level, conducting analysis gap, and providing recommendations and suggestions for improvement. The research method used is the Quantitative Analysis Method.The results of the research are the current capability level for the APO12 domain (manage risk) with a value of 2.87 , which means that at level 2 (managed process), it means that IT processes in the service of Quality Control PT. Woolu Aksara Maya Yogyakarta has been carried out, achieved, and managed well. The level of capability expected by PT. Woolu Aksara Maya is at level 3 (established process. Domain APO12 (manage risk) gets a value gap of 0.13. Domain EDM03 (ensure risk optimization) gets a capability value of 3.00 (established process) and the results of calculating the Gap value get a value of 0.00 . The recommendations generated in this research are by the expected goals.
\end{abstract}

\section{Keywords}

COBIT 5, Quality Control, Capability Level, gap

\section{INTRODUCTION}

Quality problems have caused the company's overall strategy to remain competitive and survive in global competition with other companies products[1]. A good process will produce good quality and be produced according to market demand by predetermined quality standards. The reality in this area shows that successful and viable companies must implement quality plans. With high-quality planning, the company can deal with waste effectively and improve the competitiveness of the company's business[2].
Quality Control referred to at PT. Woolu Aksara Maya is controlling the process of making company web applications so that it is hoped that there will be no bugs or errors that occur in the company's web applications. Services Quality Control at PT. Woolu Aksara Maya still has many bugs or errors in the company's web application, so it will cause risks that will arise when the company's business processes are running. This proves the need for management to handle the risks that are likely to arise that will affect the business processes carried out by PT. Woolu Maya script. The organization needs to assess the risks in terms of positive and negative that will be caused so that later a solution will be given to the potential risks that will arise. The assessment consists of several stages which include analysis of capability level, gap, and risk assessment[3].The assessment stage will produce a recommendation and mitigation measures that can be used by PT. Woolu Aksara Maya, from some of the background problems above, this research will have a title, namely "Analysis of Risk Management Assessment on Quality Control Services Using Framework Cobit 5".

\section{LITERATURE STUDIES}

\subsection{Understanding Analysis}

According to[4] analysis can be defined as the decomposition of a complete data system into its parts to identify and evaluate problems, opportunities, obstacles that occur, and the expected needs so that improvements can be proposed.

\subsection{Information Technology Risk Management}

According to[5]risk management is a detailed process to identify factors that can damage or disclose data, evaluate these factors in terms of data value and the cost of countermeasures, and implement motivating solutions for risk mitigation or reduction.

\subsection{Understanding Quality}

According to[1] Quality or quality is a trait or characteristic that distinguishes one another. Quality or quality is an activity (business management) that aims to maintain and manage the quality of the company's products and services as planned.

\subsection{Understanding Control}

Control or supervision is to ensure that the results obtained are in line with expectations. Control or supervision is the activity of identifying and controlling what happens, and in controlled activities so that these activities are as expected or planned[6]. 


\subsection{COBIT 5}

COBIT 5 is one of the means to help companies create optimal value in managing information technology governance so that the company can finally achieve its vision and mission. According to [7]COBIT 5 is the only framework for governance and management of information technology. COBIT 5 incorporates the latest thinking in corporate governance and management techniques, providing globally accepted principles, practices, analytical tools, and models to help increase the trust and value of information systems [8].

\subsection{Basic Principles of COBIT 5}

Based on the explanation in the 2012 ISACA journal, Control Objectives for Information and Related Technology (COBIT)[9] in general have five basic principles as shown in Figure 1:

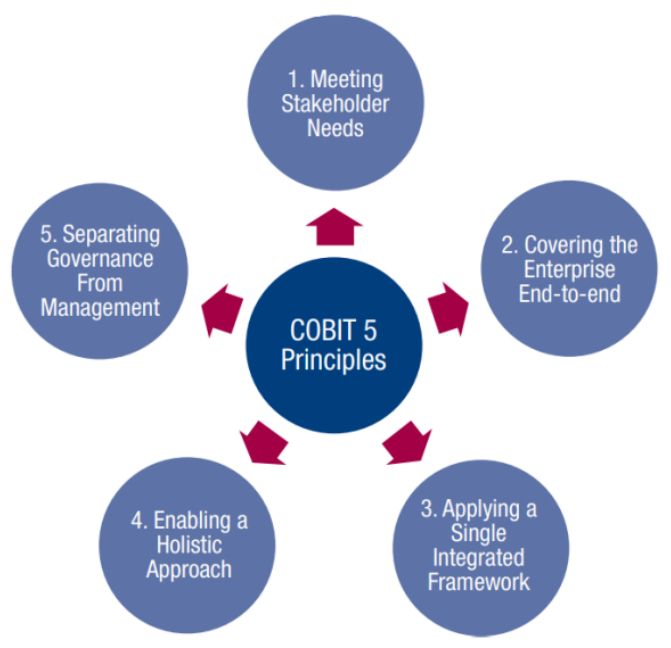

Figure 1:COBIT 5 principles

a. Principle 1

Fulfillmentneeds Stakeholder each company has a different vision and mission.

b. Principle 2

Covering the enterprise End-to-End considers all IT governance and management enablers for the enterprise.

c. $\quad$ Principle 3

Implement an integrated Single Framework Cobit 5 can adapt to IT governance and management in the company

d. Principle 4 Enabling a holistic approach COBIT 5 defines a set of enablers to support the implementation of comprehensive governance and IT management system for the enterprise.

e. Principle 5 Separation between Governance and Management [8].

\subsection{Implementation of COBIT 5}

According to [8] there are 7 stages in implementing COBIT 5. The application can be seen in Figure 2:

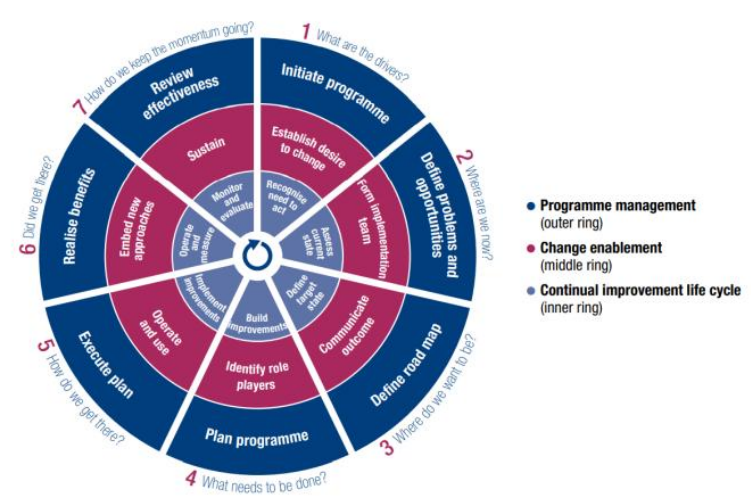

Figure 2:The seven phases of the implementation life cycle

1. Stage 1

What is the driver (Initiative Program)?

The first step is to identify who is in control to support change and create the will to achieve goals at the executive level. Then, when implemented as a new process, controllers can be sourced from internal and external parties and the existence of issues allows them to become supporters of change drivers. Examplesof change drivers include events, trends, performance issues, software implementation, and company goals[10].

2. Stage 2

Where are we now (Define Problems and Opportunities)?

Ensure that IT goals are matched with company strategy and risk and prioritize company goals, IT goals, and most important IT processes[11].

3. $\quad$ Stage 3

Where do we want to be (Define RoadMap)?

The third step is to determine the goals for making improvements, which is then followed by an analysis gap to identify relevant alternative solutions that are fast and costeffective.

4. Stage 4

What to do (Plan Program)?

The fourth step describes how to find a practical solution to use by identifying the supported project in a legitimate business case and creating an implementation change plan.

5. Stage 5

How to go there (Execute Plan)?

The fifth step is to implement the proposed solution into the practice of daily activities and establish a calculation and monitoring system to ensure business conformity is achieved and performance can be measured.

6. Stage 6

Do you get there (Release Benefits)?

The sixth step focuses on improving management and transforming the ongoing transition from management practices to business operations, monitoring performance improvements using performance and profit plans, and expected results.

7. Stage 7

How to maintain momentum (Review Effectiveness)?

The seventh step assesses the overall success of the business, identifies governance or other management needs, and reinforces ongoing needs[12].

\subsection{Capability Level}

ISO/IEC 15505 defines the criteria for assessing the process capability of the COBIT framework. Process capability is assigned to 6 point levels from 0 to 5 , which represents an increase in the capability of the ongoing process [13]. 
1. Level 0 -incomplete Process The

company at this stage does not carry out the IT processes that should exist or has not succeeded in achieving the objectives of the IT process.

2. Level 1 -Performed Process The

company at this stage has successfully implemented IT processes and the objectives of the IT process have been achieved.

3. Level 2-Managed Process

At this stage, the company in carrying out IT processes and achieving its goals is carried out in a well-managed manner, so that there is more assessment because the implementation and achievements are carried out with good management. Management is a process of planning, evaluating, and adjusting for a better direction[14].

4. Level 3-Established Process The

company at this stage has standardized IT processes within the scope of the company as a whole. This means that they already have process standards that apply throughout the company.

5. Level 4 - Predictable Process

Companies at this stage have implemented IT processes within definite boundaries, for example, time constraints. These limits are generated from the measurements that have been made at the time the IT process was implemented.

6. Level 5 - Optimizing Process

At this stage, the company has made innovations and made continuous improvements to improve its capabilities[15].

\subsection{RACI Chart}

RACI stands for: Responsible, Accountable, Consulted, and Informed. RACI Charts make it easy to map and differentiate key tasks by location, such as executive areas that need to be in a company to help run existing business processes[16].

\subsubsection{RACI ChartEDM03}

The processes that exist in the EDM03 domain:

1. EDM03.01 (Evaluating Risk Management) this process aims to evaluate and conduct an assessment of the direct impact and long-term impact of the risk of using IT on the organization.

2. EDM03.02 (Direct Risk Management) this process aims to direct the implementation of risk management to ensure that IT risk management must be able to ensure that IT risks do not exceed the risks of organizational growth.

3. EDM03.03 (Risk Management Monitoring) this process develops how IT risk issues are identified, tracked, and reported[17].

Here is theEDM03RACI Chart.

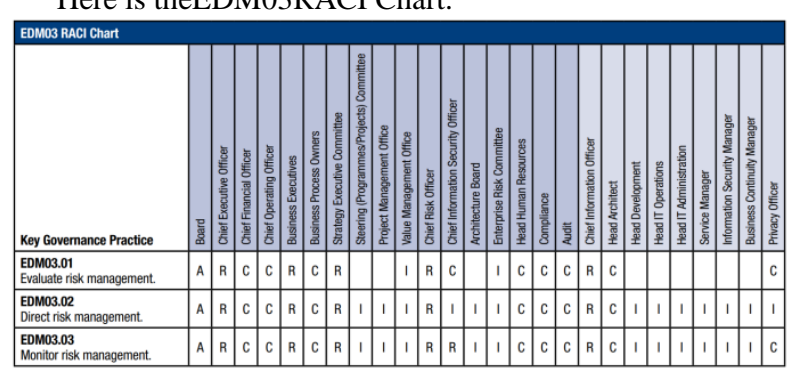

\section{Figure 3:RACI Chart EDM03}

RACI Chart in Figure 3 is used for the EDM03 domain so that researchers can map prospective respondents to a survey that will be used for data processing. RACI identification is based on people who are directly involved in the business processes of PT. Woolu Maya script. The RACI Chart above is taken based on the tasks of each individual who is at PT. Woolu Maya script.

\subsubsection{RACI ChartAPO12}

Domain APO12 is a domain that exists in COBIT 5, APO12 focuses on IT risk management[18]. The six subdomains associated with APO12 are:

1. APO12.01 (Data collection) domain contains official rules regarding the technical stages of data collection.

2. APO12.02 (Analyzing Risk) this process includes developing useful information to support risk decisionmaking into relevant business risk factors.

3. APO12.03 (Maintaining Risk Profile) This process includes maintaining a repository of known risks and their attributes, such as expected frequency, potential impact, and response from related resources, as well as capabilities and controls being implemented.

4. APO12.04 (Articulate Risk) This process provides information on current IT-related conditions and opportunities at the right time according to stakeholder needs to make appropriate responses.

5. APO12.05 (Determining a Portfolio of Management Actions) Risk This process includes managing opportunities in reducing the occurrence of risk to an acceptable level as a portfolio.

6. APO12.06 (Responding to Risks) This process includes periodic responses with effective measurements of the limit of losses from events involving IT[19].

Here is the APO12RACI Chart:

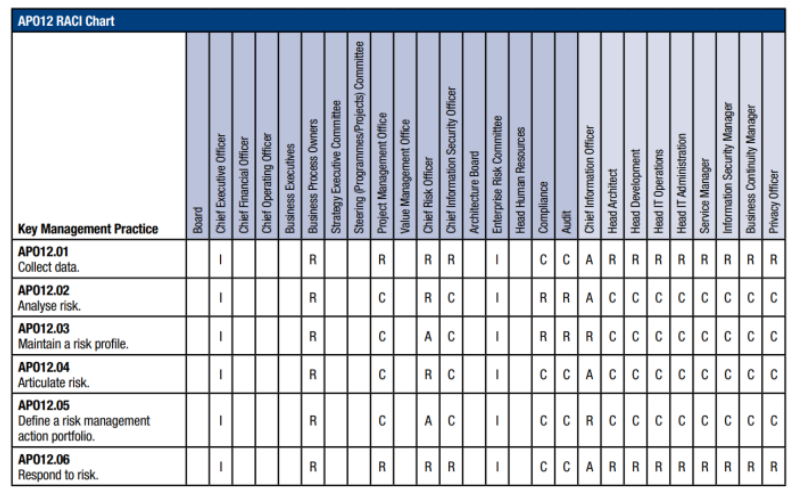

\section{Figure 4:RACI ChartAPO12}

RACI Chart in Figure 4 is used for the APO12 domain so that researchers can map prospective respondents who will fill out questionnaires that will later be used as data processing materials. RACI identification is taken based on the people who are directly involved in the business processes of PT. Woolu Aksara Maya, basically the parties in PT. Woolu Aksara Maya has been individually involved as an actor from the RACI Chart, both actors implementing tasks, Decision Making, giving directions and roles that must understand the decisions taken, so it can be concluded that the elements in PT. Woolu Aksara Maya takes part in the RACI Chart actor based on the person who carries out the task of running the business process (responsible) which is used as a reference for selecting respondents[20].

\section{METHODOLOGY}

\subsection{Data Collection Method}

1. Observational 
Observation is an activity to directly observe an object in detail and to find information and problems that will be studied in this research. In this research, observations were made by researching and understanding services quality control at PT. Woolu Maya script Yogyakarta[21].

2. Interview

The interview is one of the literature studies conducted by conducting questions and answers between two or more people by meeting face to face between the interviewer and the interviewee. This interview was conducted to obtain accurate information from trusted sources[11].

3. Questionnaire

The questionnaire is a data collection technique that is carried out by giving a set of questions or written statements to respondents to answer. Questionnaires will be distributed to respondents who specifically understand Quality Control.The distribution of questionnaires will be done by distributing questionnaire sheets directly to the respondents. The researcher will explain about the questionnaire if there are questions from the respondents. Because this is more effective for respondents understanding of the questions asked in the questionnaire[13].

\subsection{Research Stages}

This chapter will explain the methodology in the research to be carried out. The stages of this research are carried out so that the work steps become more systematic and directed. The following are the stages of the research work that will be carried out as shown in Figure 5:

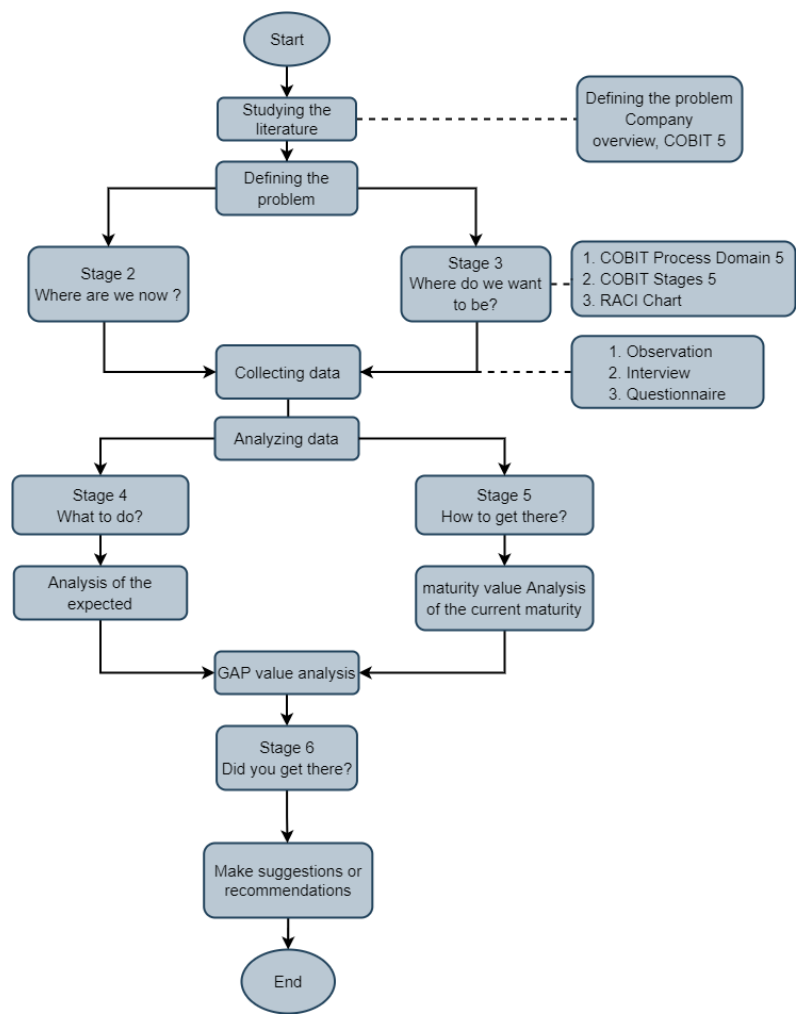

Figure 5:Research Stage

1. Research begins by conducting a literature research. A literature research was conducted to get an overview of the company that was the object of research and also to looks for the COBIT 5 theory that supports this research.
2. After conducting a literature research and getting the problem to be solved, the researcher will define the problem using the process domain in COBIT 5, COBIT 5 stages, and the RACI Chart. At the stage of defining this problem, it has also entered the stages of COBIT 5 itself, namely at stage 2 (where are we now?) and stage 3 (where do we want to be?).

3. The third stage is collecting data. After the researcher defines the problem, the researcher will collect data to solve the problem by conducting observations, interviews, and also questionnaires which are expected to solve the problem.

4. The fourth stage is analyzing the data. After collecting the required data from observations, interviews, and questionnaires, the researcher analyzed the expected data by analyzing the expected maturity value and also by analyzing the current maturity value. At the stage of analyzing the data, it has entered the stages of COBIT 5 itself, namely at stage 4 (what to do?) and stage 5 (how to go there?).

5. The fifth stage is the analysis of the GAP value. At this stage, it has entered the stages of COBIT 5, namely at stage 6 (does it get there). The GAP value is the difference value obtained after the researcher calculates the expected maturity value with the current maturity value. After getting the results, the researcher will report the results to the company. If the value of the questionnaire results is greater than the expected capability value, the existing process is maintained and the researcher does not need to provide recommendations, whereas if the respondent's result value is smaller than the expected value, the researcher will provide recommendations aimed at achieving the desired level.

\subsection{Implementation}

\subsubsection{Data Collection}

The research method used is the quantitative analysis method by collecting data using questionnaires, interviews, and observations.

\subsubsection{Questionnaire}

In determining research respondents using the RACI Chart method which aims to make it easier to map and distinguish the main tasks that are in, show, assessing the assessing each work unit or the duties of the existing staff to assist the running of the company's business processes. Researchers have distributed questionnaire sheets to respondents by mapping respondents based on the following RACI Chart method[9]:

Table 1. Results of mapping respondents RACI ChartAPO12

\begin{tabular}{|c|l|c|}
\hline No & \multicolumn{1}{|c|}{ Unit COBIT 5 } & ID \\
\hline 1. & Business Process Owner & $\mathrm{R} 1$ \\
\hline 2. & Project Management Office & $\mathrm{R} 2$ \\
\hline 3. & Chief Risk Officer & $\mathrm{R} 2$ \\
\hline 4. & Chief Information Security Officer & $\mathrm{R} 5$ \\
\hline 5. & Head Architect & $\mathrm{R} 5$ \\
\hline 6. & Head Development & $\mathrm{R} 2$ \\
\hline 7. & Head IT Operations & $\mathrm{R} 5$ \\
\hline 8. & Head IT Administration & $\mathrm{R} 4$ \\
\hline 9. & Service Manager & $\mathrm{R} 4$ \\
\hline
\end{tabular}




\begin{tabular}{|c|l|c|}
\hline 10. & Information Security Manager & R3 \\
\hline 11. & Business Continuity Manager & R3 \\
\hline 12. & Privacy Officer & R5 \\
\hline 13. & Compliance & R4 \\
\hline 14. & Audit & R5 \\
\hline 15. & Chief Information Officer & R5 \\
\hline
\end{tabular}

Based on table 1 above, the results of mapping the RACI Chart domain APO12 (manage risk) on the service Quality Control PT. Woolu Aksara Maya Yogyakarta is 15 work units that have been matched with work units on services Quality Control and resulted in five respondents who will fill out the research questionnaire because there are several work units carried out by the same person. The following is a table of the results of mapping respondents from the RACI Chart in the EDM03 domain. The table of respondent mapping results can be seen in Table 2[9]:

Table 2. Results of mapping respondents RACI ChartEDM03

\begin{tabular}{|c|l|c|}
\hline No & \multicolumn{1}{|c|}{ Unit COBIT 5 } & ID \\
\hline 1. & Chief Executive Officer & R3 \\
\hline 2. & Business Executives & R2 \\
\hline 3. & Strategy Executive Committee & R2 \\
\hline 4. & Chief Risk Officer & R2 \\
\hline 5. & Chief Information Officer & R5 \\
\hline
\end{tabular}

Based on table 2 above, the results of mapping the RACI Chart domain EDM03 (ensure risk optimization) on the service Quality Control PT. Woolu Aksara Maya Yogyakarta is 5 work units that have been matched with work units on services Quality Control and resulted in five respondents who will fill out the research questionnaire because there are several work units carried out by the same person.

\subsubsection{Observation and Interview}

At the stage of observation and interviews were conducted to obtain relevant data related to the research topic. The interviewaims to obtain valid data so that the results of the research can be maintained to completion. The following are the results of interviews conducted by researchers.

1. The Capability Level value of expected the company is 3

2. Overview of the content division of PT. Woolu Maya script.

3. Business processes in the content division of PT. Woolu Maya script.

4. Problems that exist in services Quality Control

5. Find solutions to these Quality Control problems together.

6. Duties and responsibilities of staff in the content division of PT. Woolu Maya script.

7. The organizational structure of the content division of PT. Woolu Maya script.

8. Quality Control is the show assessing the content division of PT. Woolu Maya script.

9. Management risks that may occur in-services Quality Control which is expected to be overcome by risk management assessment using the COBIT 5 framework using the APO12 (process domain manage risk) and EDM03 (ensure risk optimization)

\subsubsection{Data Analysis}

\subsubsection{Current Level Capability}

In this stage, the researchers processed the questionnaire data obtained from the respondents. At this stage, the researcher used the Guttman Scale calculation. The Guttman scale provides concise and strong responses to respondents' responses. The researcher will use the answers [Yes] and [No] then the answers will be collected based on the weight of the answers. The weight of the answer is worth 1 if the respondent answers [Yes], and the answer is worth 0 if the respondent answers [No].The calculation results can be seen in Table 3:

Table 3. Current capability APO12

\begin{tabular}{|l|l|c|}
\hline \multicolumn{1}{|c|}{ Domain } & \multicolumn{1}{c|}{ Process } & Current Level \\
\hline APO12.01 & Collecting Data & 2.70 \\
\hline APO12.02 & Analyzing risk & 2.71 \\
\hline APO12.03 & $\begin{array}{l}\text { Maintaining a risk } \\
\text { profile }\end{array}$ & 3.00 \\
\hline APO12.04 & Articulating risk & 3.00 \\
\hline APO12.05 & $\begin{array}{l}\text { Determining risk } \\
\text { management } \\
\text { portfolio }\end{array}$ & 2.90 \\
\hline APO12.06 & $\begin{array}{l}\text { Responding to } \\
\text { risk }\end{array}$ & 2.90 \\
\hline
\end{tabular}

Based on the calculation of the APO12 domain questionnaire (managed risk) in table 3 above using the Guttman scale calculation, it gets a value of 2.87 (managed process). This value is obtained from the calculation of the average Current Level divided by the number of domain processes. At APO12, it produces a value of 2.87 , which means that at this level it can be said that the implementation of business processes in services Quality Control PT. Woolu Aksara Maya has carried out planning, supervision, and adjustment and the results of its work have been determined, supervised, and cared for properly.

The following is a table of calculation results using the EDM03 domain (ensure risk optimization). The table of calculation results can be seen in Table 4:

Table 4. Current capability EDM03

\begin{tabular}{|c|l|c|}
\hline Domain & \multicolumn{1}{|c|}{ Process } & Current Level \\
\hline EDM03.01 & $\begin{array}{l}\text { Evaluating risk } \\
\text { management }\end{array}$ & 3.00 \\
\hline EDM03.02 & $\begin{array}{l}\text { Directing risk } \\
\text { management }\end{array}$ & 3.00 \\
\hline
\end{tabular}

Based on table 4 above obtained a value of 3.00 in the calculation current level. at this level, it can be said that the company already has standardized IT processes within the scope of the company as a whole and has been applied throughout the company.

\subsubsection{Expected Level Capability Capability}

value desired by PT. Woolu Aksara Maya Yogyakarta onservices, Quality Control which is at level 3. At this level, the company already has standardized IT processes within the scope of the company as a whole. This means that they already have process standards that apply throughout the company.

\subsubsection{GAP Value Analysis The GAP}

The value obtained in the APO12 domain (manage risk) is 0.13 . While the EDMO3 domain (ensure risk optimization) is 
0.00, this means that the service of Quality Control PT. Maya's Woolu has reached the desired level and only needs the advice to maintain the level already reached.

\subsubsection{Assessment Results}

In this subsection, the known values will be presented. The results of the calculation of the capability value can be seen in Table 5:

Table 5. Value of gap domain APO12

\begin{tabular}{|c|l|l|l|l|l|}
\hline Domain & Process & $\begin{array}{c}\text { Cur } \\
\text { rent }\end{array}$ & $\begin{array}{c}\text { Exp } \\
\text { ecte } \\
\boldsymbol{d}\end{array}$ & Max & $\begin{array}{c}\text { GA } \\
\boldsymbol{P}\end{array}$ \\
\hline APO12.01 & $\begin{array}{l}\text { Collecting } \\
\text { Data }\end{array}$ & 2.70 & 3.00 & 5.00 & 0.30 \\
\hline APO12.02 & $\begin{array}{l}\text { Analyzing } \\
\text { risk }\end{array}$ & 2.71 & 3.00 & 5.00 & 0.29 \\
\hline APO12.03 & $\begin{array}{l}\text { Maintaining } \\
\text { risk profile }\end{array}$ & 3.00 & 3.00 & 5.00 & 0.00 \\
\hline APO12.04 & $\begin{array}{l}\text { Articulate } \\
\text { risk }\end{array}$ & 3.00 & 3.00 & 5.00 & 0.00 \\
\hline APO12.05 & $\begin{array}{l}\text { Determine } \\
\text { risk } \\
\text { managemen } \\
\text { t portfolio }\end{array}$ & 2.90 & 3.00 & 5.00 & 0.10 \\
\hline APO12.06 & $\begin{array}{l}\text { Respond to } \\
\text { risk }\end{array}$ & 2.90 & 3.00 & 5.00 & 0.10 \\
\hline \multicolumn{2}{|c|}{ Average Current Level } & $\mathbf{2 . 8 7}$ & \multicolumn{2}{|c|}{$\begin{array}{c}\text { Average } \\
\text { Gap }\end{array}$} & $\mathbf{0 . 1 3}$ \\
\hline
\end{tabular}

Based on table 5 above it can be concluded that the Quality Control service of PT. Woolu Aksara Maya reached level 2, which means the company in carrying out IT processes has achieved its goals and has been managed well, so there is more assessment because the implementation and achievements are carried out with good management.

In the following table, the results of the Capability Level show domain EDM03 (ensure risk optimization) that have been known. The gap value table can be seen in Table 6:

Table 6. Gap domain value EDM03

\begin{tabular}{|l|l|l|l|l|l|}
\hline Domain & Process & $\begin{array}{c}\text { Cur } \\
\text { rent }\end{array}$ & $\begin{array}{c}\text { Exp } \\
\text { ecte } \\
\boldsymbol{d}\end{array}$ & Max & $\begin{array}{c}\boldsymbol{G A} \\
\boldsymbol{P}\end{array}$ \\
\hline $\begin{array}{l}\text { EDM03.0 } \\
1\end{array}$ & $\begin{array}{l}\text { Evaluating } \\
\text { risk } \\
\text { management }\end{array}$ & 3.00 & 3.00 & 5.00 & 0.00 \\
\hline $\begin{array}{l}\text { EDM03.0 } \\
2\end{array}$ & $\begin{array}{l}\text { Directing risk } \\
\text { management }\end{array}$ & 3.00 & 3.00 & 5.00 & 0.00 \\
\hline \multicolumn{2}{|c|}{ Average Current Level } & $\mathbf{3 . 0 0}$ & $\begin{array}{l}\text { Average } \\
\text { Average } \\
\text { Gap }\end{array}$ & $\mathbf{0 . 0 0}$ \\
\hline
\end{tabular}

Based on table 6 above, it can be concluded that the service Quality Control has reached the expected level and got a GAP value of 0.00 for all existing domains.

Based on the results of the calculation of the value of the Capability Level domain APO12 and EDM03 have reached the level in each domain of the process. To prove that Quality Control in the Content division of PT. Woolu Aksara Maya has reached level 1 (performed process), level 2 (manage the process) so it must have valid data requirements at level 1 (performed process) and level 2 (manage the process). The following is the completeness of data requirements that have been owned by Quality Control PT. Woolu Maya script corresponds to the APO12 and EDM03 domains. The complete list of needs can be seen in table 7:
Table 7.Complete list of data requirements for level 1

\begin{tabular}{|c|c|c|}
\hline \multicolumn{3}{|c|}{ PA 1.1 (Process Performed) } \\
\hline Domain & Goal & $\begin{array}{l}\text { Descri } \\
\text { ption }\end{array}$ \\
\hline $\begin{array}{l}\text { APO12. } 01 \\
\text { (Collecting Data) }\end{array}$ & $\begin{array}{l}\text { Collecting data to } \\
\text { analyze risk }\end{array}$ & $\checkmark$ \\
\hline $\begin{array}{l}\text { APO12.02 } \\
\text { (Analyzing Risk) }\end{array}$ & Analyzing risk data. & $\boldsymbol{V}$ \\
\hline $\begin{array}{l}\text { APO12.03 } \\
\text { (Maintaining Risk } \\
\text { Profile) }\end{array}$ & $\begin{array}{l}\text { Maintaining risk } \\
\text { attributes. }\end{array}$ & $\boldsymbol{V}$ \\
\hline $\begin{array}{l}\text { APO12.04 } \\
\text { (Articulate Risk) }\end{array}$ & $\begin{array}{l}\text { Provides information on } \\
\text { IT risk opportunities. }\end{array}$ & $\checkmark$ \\
\hline $\begin{array}{l}\text { APO12.05 } \\
\text { (Defining a Portfolio of } \\
\text { Risk Management } \\
\text { Actions) }\end{array}$ & $\begin{array}{l}\text { Managing opportunities } \\
\text { to minimize risks }\end{array}$ & $\checkmark$ \\
\hline $\begin{array}{l}\text { APO12.06 } \\
\text { (Responding to Risks) }\end{array}$ & $\begin{array}{l}\text { Responding } \\
\text { appropriately to IT } \\
\text { risks. }\end{array}$ & $\boldsymbol{\nu}$ \\
\hline $\begin{array}{l}\text { EDM03.01 } \\
\text { (Evaluating Risk } \\
\text { Management) }\end{array}$ & $\begin{array}{l}\text { Evaluating and } \\
\text { assessing the use of IT }\end{array}$ & 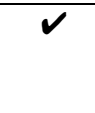 \\
\hline $\begin{array}{l}\text { EDM03.02 } \\
\text { (Directing Risk } \\
\text { Management) }\end{array}$ & $\begin{array}{l}\text { Directing the } \\
\text { implementation of IT } \\
\text { risk management }\end{array}$ & $\checkmark$ \\
\hline
\end{tabular}

Based on table 7 above, it can be seen that the completeness of data requirements at level 1 in each process domain has been fulfilled and can be interpreted with PA scale (Process Attribute) with attribute value > 85\% - 100\% F (Full Achieved). To be able to reach level 2, Quality Control in the content division of PT. Woolu Aksara Maya must meet the requirements at level 2 . The following is the completeness of data requirements that have been owned by Quality Control in the content division of PT. Woolu Maya script corresponds to the APO12 and EDM03 domains.

The complete list of data requirements can be seen in Table 8:

Table 8.Completeness of data requirements

\begin{tabular}{|c|c|c|c|c|}
\hline \multirow{2}{*}{ No } & \multirow{2}{*}{$\begin{array}{c}\text { PA 2.1 } \\
\text { (Performed } \\
\text { Management) }\end{array}$} & \multirow{2}{*}{ Evidence } & \multicolumn{2}{|c|}{ Description } \\
\hline & & & Yes & No \\
\hline 1. & $\begin{array}{l}\text { Scope of risk } \\
\text { management }\end{array}$ & $\begin{array}{l}\text { Organizational } \\
\text { structure }\end{array}$ & $\checkmark$ & \\
\hline 2. & $\begin{array}{l}\text { Objectives of risk } \\
\text { management }\end{array}$ & $\begin{array}{l}\text { Tasks of each } \\
\text { staff }\end{array}$ & $\checkmark$ & \\
\hline 3. & $\begin{array}{l}\text { Response of } \\
\text { service Quality } \\
\text { Control if it does } \\
\text { not meet the target }\end{array}$ & Jo & & $V$ \\
\hline 4. & $\begin{array}{l}\text { RACI Chart } \\
\text { management } \\
\text { Stakeholder }\end{array}$ & - & & $\checkmark$ \\
\hline 5. & $\begin{array}{l}\text { criteria for } \\
\text { recruitment of } \\
\text { employees }\end{array}$ & $\begin{array}{l}\text { handbook } \\
\text { training and } \\
\text { recruitment of } \\
\text { employees }\end{array}$ & $\checkmark$ & \\
\hline 6. & employee training & $\begin{array}{l}\text { handbooks } \\
\text { training and } \\
\text { recruitment of } \\
\text { employees }\end{array}$ & $\checkmark$ & \\
\hline
\end{tabular}


Based on table 8 above it can be seen that the completeness of the data requirements at level 2 domain APO12 and EDM03 some supporting documents are not owned by the service Quality Control to meet the completeness at level 2 (manage the process) thus at this level is calculated using the PA scale it has an attribute value of $>50 \%-85 \% \mathrm{~L}$ (Largely Achieved). Furthermore, the complete list of level 2 data on Work Product Management domain APO12 and EDM03 service Quality Control PT. Woolu Maya script. The complete list of data requirements can be seen in Table 9:

Table 9.Completeness of data requirements

\begin{tabular}{|c|c|c|c|c|}
\hline \multirow{2}{*}{$\begin{array}{l}\text { No } \\
\cdot\end{array}$} & \multirow{2}{*}{$\begin{array}{c}\text { PA } 2.2 \text { (Work } \\
\text { Product } \\
\text { Management) }\end{array}$} & \multirow{2}{*}{ Evidence } & \multicolumn{2}{|c|}{ Remarks } \\
\hline & & & Yes & No \\
\hline 1 & $\begin{array}{l}\text { List of jobs that } \\
\text { must be done by } \\
\text { each staff }\end{array}$ & $\begin{array}{l}\text { Manual } \\
\text { training and } \\
\text { recruitment } \\
\text { employee }\end{array}$ & $\boldsymbol{\nu}$ & \\
\hline 2 & $\begin{array}{l}\text { Documents or } \\
\text { lists of job } \\
\text { requirements } \\
\text { that must be } \\
\text { completed by } \\
\text { each staff. }\end{array}$ & $\begin{array}{l}\text { Employee SOP } \\
\text { document }\end{array}$ & $\checkmark$ & \\
\hline 3 & $\begin{array}{l}\text { Documents or } \\
\text { work results that } \\
\text { have been } \\
\text { completed by } \\
\text { each staff }\end{array}$ & $\begin{array}{l}\text { Employee } \\
\text { monthly report } \\
\text { document }\end{array}$ & $\checkmark$ & \\
\hline 4 & $\begin{array}{l}\text { Evaluation of } \\
\text { the work of each } \\
\text { staff }\end{array}$ & $\begin{array}{l}\text { Employee } \\
\text { monthly report } \\
\text { document }\end{array}$ & $\checkmark$ & \\
\hline
\end{tabular}

Based on table 9 above the complete list of requirements in the APO12 (manage risk) and EDM03 (ensure risk optimisation) domains to reach level 2 in Work Product Management has been fully achieved. This, if calculated using the PA scale, has an attribute value of $>85-100 \% \mathrm{~F}$ (Full Achieved).The following is a graph of the values Gap and Current Level for each APO12 and EDM03 domain. The graph of the value gap and Current Level can be seen in Figure 6:

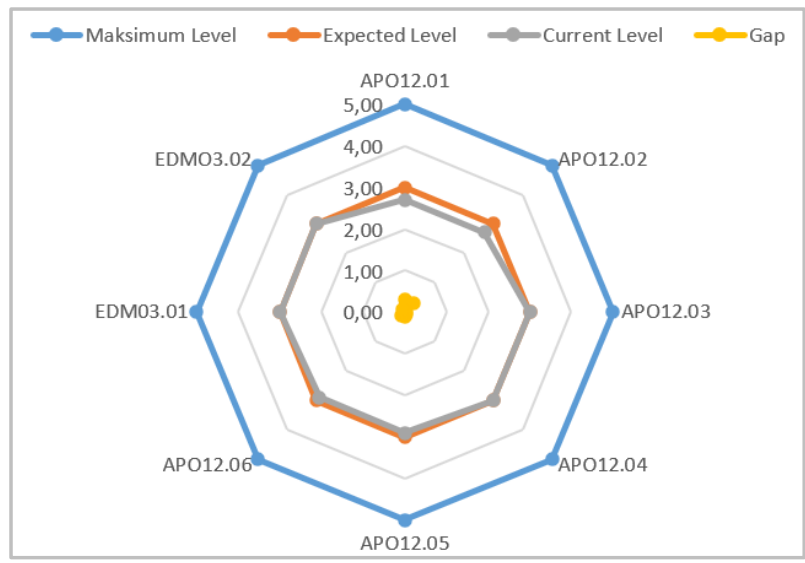

Figure 6: The graph of the values of gap APO12 and EDM03

Figure 6 above is a graph of the values expected by PT. Woolu Maya script, the value of the questionnaire, and the value of the gap in each domain used in the research.

\subsubsection{Recommendations and Reporting Results}

In this sub-chapter, the researcher will present recommendations and suggestions that have been obtained from the results of the analysis of the values gap obtained and will be implemented by the content division at the service of Quality Control PT. Woolu Maya script. The results of recommendations and suggestions can be seen in Table 10

Table 10.Domain recommendationsAPO12 and EDM03

\begin{tabular}{|c|c|}
\hline Domain & Recommendation \\
\hline $\begin{array}{l}\text { APO12.01 } \\
\text { (Collect Data) }\end{array}$ & $\begin{array}{l}\text { a. Service Quality Control must } \\
\text { schedule in reporting the data } \\
\text { associated with IT risks that might } \\
\text { occur in the future, and conduct } \\
\text { meetings or find a way out or to } \\
\text { overcome the possible risk. } \\
\text { b. Service Quality Control must have } \\
\text { staff who are experts in taking care of } \\
\text { the data records of both internal and } \\
\text { external IT risk management } \\
\text { c. Service Quality Control must have a } \\
\text { backup containing the data database } \\
\text { and MOU process to be used in } \\
\text { further investigations. } \\
\text { d. Service Quality Control must prepare } \\
\text { care plans that have been made to run } \\
\text { properly } \\
\text { e. Service Quality Control must keep } \\
\text { records or documents the results of } \\
\text { the meeting or meetings that discuss } \\
\text { further investigations related to IT. }\end{array}$ \\
\hline $\begin{array}{l}\text { APO12.02 } \\
\text { (Analyzing } \\
\text { Risk) }\end{array}$ & $\begin{array}{l}\text { a. Services Quality Control must include } \\
\text { material that in-depth discusses } \\
\text { increasing risk factors in employee } \\
\text { recruitment documents. } \\
\text { b. Service Quality Control must make } \\
\text { improvements in IT governance } \\
\text { processes including risk management } \\
\text { relating to the use of IT. } \\
\text { c. Service Quality Control must have an } \\
\text { agreed standard associated with IT } \\
\text { risk, as well as the need to conduct } \\
\text { risk mapping to assist in making } \\
\text { further decisions. }\end{array}$ \\
\hline $\begin{array}{l}\text { APO12.05 } \\
\text { (Reducing the } \\
\text { impact of risk to } \\
\text { a level that is } \\
\text { acceptable to } \\
\text { the } \\
\text { portfolio/toleran } \\
\text { ce value) }\end{array}$ & $\begin{array}{l}\text { a. Services Quality Control must have } \\
\text { thorough preparation in testing the } \\
\text { agreed plan so that when a risk } \\
\text { occurs, the plan can overcome the } \\
\text { current risk. } \\
\text { b. Service Quality Control must have a } \\
\text { governing document within the limits } \\
\text { of the tolerable risk that these risks do } \\
\text { not impede the course of business } \\
\text { processes. }\end{array}$ \\
\hline $\begin{array}{l}\text { APO12.06 } \\
\text { (Responding to } \\
\text { Risk) }\end{array}$ & $\begin{array}{l}\text { a. Services Quality Control must check } \\
\text { the loss from beginning to end when a } \\
\text { problem occurs and report the loss to } \\
\text { management and administration. }\end{array}$ \\
\hline
\end{tabular}


Table 11.Domain suggestion APO12 and EDM03

\begin{tabular}{|c|c|}
\hline Domain & Suggestion \\
\hline $\begin{array}{l}\text { APO12.03 } \\
\text { (Maintaining Risk } \\
\text { Profile) }\end{array}$ & $\begin{array}{l}\text { a. Service Quality Control must } \\
\text { continue to maintain the effort that } \\
\text { has been done before and improve } \\
\text { other ancillary factors so that } \\
\text { business processes can be run well. } \\
\text { b. Service Quality Control must } \\
\text { continue to maintain and enhance } \\
\text { the company's efforts to define IT } \\
\text { services that business processes } \\
\text { continue to survive amid fierce } \\
\text { global competition as well as adding } \\
\text { staff who are experts in running the } \\
\text { company's business processes so } \\
\text { that business processes better } \\
\text { function. }\end{array}$ \\
\hline $\begin{array}{l}\text { APO12.04 } \\
\text { (Articulate Risk) }\end{array}$ & $\begin{array}{l}\text { a. Services Quality Control must have } \\
\text { relationships with other divisions to } \\
\text { support business processes. } \\
\text { b. Service Quality Control must have } \\
\text { SOPs that regulate the management } \\
\text { of IT-related business processes, } \\
\text { including determining the analysis } \\
\text { of gaps that can lead to greater } \\
\text { losses. }\end{array}$ \\
\hline $\begin{array}{l}\text { EDM03.01 } \\
\text { (Evaluate Risk } \\
\text { Management) }\end{array}$ & $\begin{array}{l}\text { a. Service Quality Control continues to } \\
\text { make efforts to improve the } \\
\text { evaluation of IT risk measures that } \\
\text { have been used so that risks do not } \\
\text { reappear. } \\
\text { b. Service Quality Control continues to } \\
\text { make efforts to evaluate and } \\
\text { improve other supporting factors } \\
\text { and make decisions together. }\end{array}$ \\
\hline $\begin{array}{l}\text { EDM03.02 } \\
\text { (Direct Risk } \\
\text { Management) }\end{array}$ & $\begin{array}{l}\text { a. Services Quality Control must } \\
\text { continue to maintain and improve } \\
\text { the current promotions and expand } \\
\text { promotions to a wider range. } \\
\text { b. Service Quality Control must } \\
\text { continue to maintain and improve in } \\
\text { directing the strategy, and to } \\
\text { deliberate or regular meetings to } \\
\text { take these advanced strategies. }\end{array}$ \\
\hline
\end{tabular}

\section{CONCLUSION}

Based on the calculation of the Current Level in the APO12 (manage risk) and EDM03 (ensure risk optimization) domains, the value is Capability Level 2.87 (Managed Process) for the APO12 (domain managed risk). For the EDM03 domain (ensure risk optimization) the value is Capability Level 3.00 (established process). The value gap (difference) in the APO12 (manage risk) and EDM03 (ensure risk optimization) domains have been known by using concrete calculations and getting the value gap in each domain. For the APO12 domain (manage risk) it produces avalue gap of 0.13 levels which is obtained from the calculation of Current Level in the APO12 domain (manage risk).For the APO12 domain (manage risk) it produces a value gap of 0.13 levels which is obtained from the calculation of the Current Level in the APO12 domain (manage risk). As for the EDM03 domain (ensure risk optimization) it produces a value gap of 0.00 . The results of the recommendations given are to improve risk management services Quality Control PT. Woolu Aksara Maya that has not reached the desired level requires a recommendation and steps mitigation that must be carried out, namely by having a regular schedule, making SOPs on IT risk management, carried out backing up data to the database company, adding staff who are experts in analyzing risks so that new investigations are. may appear to be well known and resolved.

\section{REFERENCES}

[1] MK Hadi, "Quality Control Analysis of the Faculty of Economics and Islamic Business, Raden Intan State Islamic University (UIN) Lampung $1438 \mathrm{H} /$ 2017 M Analysis of Quality Control Against Product Damage Risk (Research At Pt. Semen Baturaja, Tbk Bandar Lampung) Thesis Submitted," P. 214, 2017.

[2] R. Sarno, "Audit Control Capability Level of Information System Governance Using COBIT 5 (Research: Directorate of ICT UPI Bandung)," J. Inf. vol. VII, no. 2, pp. 83-93, 2015.

[3] CU Putri, "Information Technology Process Risk Assessment Based on the Cobit 5 Framework at the Helpdesk of the Sub-Directorate of Information Technology and System Services, Directorate of Information Technology and System Development (DPTSI) Sepuluh Nopember Institute of Technology," Thesis, p. 241, 2017.

[4] PP Thenu, AF Wijaya, and C. Rudianto, "Information Technology Risk Management Analysis Using Cobit 5 (Case Research: Pt Global Infotech)," J. Bina Comput., vol. 2, no. 1, pp. 1-13, 2020.

[5] DA Prastiyawan, A. Ambarwati, and E. Setiawan, "Analysis of Service Risk Management Dealer Management System Using COBIT 5," Matrix J. Manaj. Technol. and Information., vol. 10, no. 2, pp. 43-49, 2020

[6] AR Rinaldi, "Quality Control using methods StatisticalQuality Control (SQC) to Minimize Failed Products at Barokah Bakery Shops," J. Chem. inf. Model., vol. 53, no. 9, pp. 1689-1699, 2017.

[7] ISACA. and JW Lainhart, COBIT 5: A business framework for the governance and management of enterprise IT COBIT 5, vol. 34, no. 1. 2012.

[8] ISACA, Implementation.USA: IT Governance Institute. 2012.

[9] ISACA, Enabling Processes. 2012.

[10] E. Rohaini, Assegaff, and Setiawan, "Evaluation of Information System Governance Using COBIT 5 at PT Sinar Sentosa Primatama Jambi," J. Ilm. MEDIA SISFO, vol. 14, no. 1, pp. 45-53, 2020.

[11] MS Lamato, A. Setyanto, A. Nasiri, U. Negeri, and G. Ung, "Evaluation of the Maturity Level of IT Infrastructure Governance Using COBIT 5," e-Jurnal JUSITI (Jurnal Sist. Inf. and Technol. Information), vol. 82, no. 2, pp. 186-197, 2019.

[12] M. Sukri and I. Riadi, "Risk Management Analysis on Administration System using OCTAVE Allegro Framework," 2021.

[13] N. Dwi Setyaningrum, Suprapto, and A. Kusyanti, "Evaluation of Information Technology Risk Management Using the COBIT 5 Framework (Case 
Research: PT. Kimia Farma (Persero) Tbk-Plant Watudakon)," J. Pengemb. Technol. inf. and Computer Science., vol. 2, no. 1, pp. 143-152, 2018.

[14] E. Anggraini, A. Dahlan, and I. Riadi, "Analysis of Risk Assessment on Electronic Services using OCTAVE Allegro Framework,” 2021.

[15] A. Andrianti and S. Assegaff, "Analysis and Design of IT Governance Using COBIT Framework in Data Management PT. BPR US," J. Manaj. Sis. inf., vol. 3, no. 2, pp. 989-998, 2018.

[16] RG Mufti and YT Mursityo, "Evaluation of Information Technology Security System Governance Using the COBIT 5 Process Focus APO13 and DSS05 Process (Research on PT Martina Berto Tbk)," J. Developer. Technol. inf. and Computer Science., vol. 1, no. 12, pp. 1622-1631, 2017.
[17] MH Arief and Suprapto, "Evaluation of Information Technology Risk Management Using the COBIT 5 Framework (Case Research at Perum Jasa Tirta I Malang)," J. Pengemb. Technol. inf. and Computer Science., vol. 2, no. 1, pp. 101-109, 2018.

[18] T. Rahayu, N. Matondang, and B. Hananto, "Audit of Academic Information Systems Using the Cobit 5 Method," J. Teknol. inf. and Educator., vol. 13, no. 1, pp. 117-123, 2020.

[19] MN Fuad and I. Riadi, "Risk Management Assessment on Human Resource Information Technology Services using COBIT 5,” 2020.

[20] S. Information and M. Cobit, "24 Rini Astuti Implementation of Information System Risk Management Using COBIT 5," pp. 24-38, 2013.

[21] Heru pratama, "Information System Security Audit at the Samsat Office in Krui City Using Cobit 5," vol. 2015, no. Sentika, 2018 